Check for updates

Cite this: RSC Adv., 2017, 7, 26921

\title{
Synthesis and evaluation of novel 12-aryl berberine analogues with hypoxia-inducible factor-1 inhibitory activity $\dagger$
}

\author{
Xiaobo Zhou, (D) † Ming Chen, (D) † Zhiyuan Zheng, (D) Guo-Yuan Zhu, (D) \\ Zhi-Hong Jiang (D) * and Li-Ping Bai (D)*
}

Eighteen novel 12-aryl berberine derivatives were synthesized and evaluated for their inhibitory effects on hypoxia-inducible factor (HIF-) 1 transcription which is a potential target for the development of anticancer agents. As a result, seven 12-phenyl berberine analogues (3a-3f, 3k) showed more potent inhibitory effect on hypoxia-induced HIF-1 transcriptional activity than the parent compound berberine (1). Notably, the 12biphenyl berberine (3e) exhibited the strongest HIF-1 suppressing activity among all the berberine analogues with an $\mathrm{IC}_{50}$ value of $0.74 \mu \mathrm{M}$. The introduction of a biphenyl substituent to berberine resulted in a 5.4 fold enhancement of potency over the parent berberine (1). Structure-activity relationship analysis revealed that the phenyl substituent is a preferential pharmacophore for HIF-1 inhibitory activity of 12 -aryl berberine analogues over heteroaromatic ring substituents of pyridyl, thienyl and furyl. The phenyls containing hydrophobic moieties are beneficial to increase the HIF-1 suppressing effect compared to those bearing hydrophilic ones. In addition, the $p$-fluoro phenyl is also a favorable pharmacophore over the $m$ - and o-fluoro phenyls. Western blot assay revealed that berberine analogues $(3 a-3 f, 3 k)$ exhibited a stronger suppressive effect on hypoxia-induced expression of HIF-1 $\alpha$ protein than berberine in both T47D and MCF-7 cells. It was also found that berberine derivatives (3a-3f, 3k) possessing more potent HIF-1 inhibitory activity generally showed a greater toxic effect on MCF-7 cancer cells. These findings may guide the rational design of berberine-based HIF-1 inhibitors for the development of anticancer drugs. This is also the first report on berberine and its derivatives' inhibitory effect on HIF-1 transcriptional activity.

Received 23rd February 2017

Accepted 9th May 2017

DOI: $10.1039 / \mathrm{c} 7 \mathrm{ra02238g}$

rsc.li/rsc-advances

\section{Introduction}

Hypoxia of solid tumors originates from the aberrant cell proliferation rate from an imbalance between oxygen supply and consumption..$^{1,2}$ Hypoxia-inducible factor 1 (HIF-1) is a principal transcription factor by which tumor cells adapt to the low oxygen microenvironment. HIF-1 plays an essential role in expression of genes involving angiogenesis, cell proliferation, survival, invasion and metastasis of solid tumors and energy metabolism. ${ }^{3}$ HIF-1 is a heterodimer composed of an oxygenregulated subunit HIF-1 $\alpha$ and a constitutively expressed subunit HIF- $1 \beta{ }^{4}$ HIF- $1 \alpha$ protein is rapidly degraded under normal conditions but stabilized under hypoxia conditions. The stabilized HIF-1 $\alpha$ is accumulated in cytosol and further

State Key Laboratory of Quality Research in Chinese Medicine, Macau Institute for Applied Research in Medicine and Health, Macau University of Science and Technology,Taipa, Macau, China.E-mail: lpbai@must.edu.mo; zhjiang@must.edu. mo

$\dagger$ Electronic supplementary information (ESI) available. See DOI: $10.1039 / \mathrm{c} 7 \mathrm{ra02238g}$

\$ Authors contribute equally. translocated to the nucleus where it dimerizes with HIF-1 $\beta$ and then binds to hypoxia response elements (HREs) together with coactivators to activate target genes, including vascular endothelial growth factor (VEGF), glucose transporter-1 (GLUT1), hexokinases etc. HIF- $1 \alpha$ is detected at increased levels in many types of human tumors, and overexpression of HIF- $1 \alpha$ correlates with poor prognosis and resistance to treatment for cancer patients. ${ }^{5}$ Therefore, HIF-1 has been regarded as a potential target for the development of anticancer agents. ${ }^{6}$

Natural products play an important role in drug discovery. A large number of inhibitors of HIF-1 activation have been identified from medicinal plants and microorganisms, ${ }^{7-15}$ such as cardiac glycosides, ${ }^{\mathbf{1 0}, 11}$ geldanamycin, ${ }^{12}$ chaetocin, ${ }^{13}$ mannasantin ${ }^{14}$ etc. Berberine (1), a major bioactive isoquinoline alkaloid from traditional Chinese medicines including Rhizoma Coptidis ("Huang-Lian" in Chinese) and Cortex Phellodendri ("Huang-Bai" in Chinese), was recently discovered to inhibit HIF- $1 \alpha$ protein expression in various carcinoma cells and enhance radiosensitivity of cancer cells. ${ }^{16-19}$ As a hotspot compound, berberine shows a wide spectrum of pharmacological effects ${ }^{20-27}$ including antihyperglycemic, ${ }^{21}$ hypolipidemic, ${ }^{22,23}$ anticancer, ${ }^{24}$ anti-inflammatory, ${ }^{25}$ neuroprotective ${ }^{26}$ 
and antimicrobial ${ }^{27}$ activities. This alkaloid was used as an OTC drug for the treatment of diarrhea in China for decades. As an efficacious and safe drug, berberine becomes a fascinating leading compound for structural modification for the development of new drug. Numerous novel berberine derivatives have been designed, synthesized and screened for medicinal application. ${ }^{28-37}$ However these derivatives mainly focus on positions of $\mathrm{C}-8,{ }^{36} \mathrm{C}-9^{29-34}$ and $\mathrm{C}-13^{35}$ of berberine by appending various types of substituents including aliphatic chains and heterocycles. There was few reports on aryl directly substituted berberine analogues or derivation of berberine at C-12 position. So far, only bromination has been performed at C-12 position of berberine. ${ }^{38,39}$ Therefore, it's desirable to study the aryl substituted effects at the $\mathrm{C}-12$ position of berberine. To promote our study on berberine, ${ }^{40-45}$ a series of novel 12 -aryl berberine analogues were designed, synthesized and evaluated for their inhibitory effect on HIF-1 transcriptional activity by using a T47D cell-based co-transfected firefly and Renilla luciferase reporter assay. Inhibition of HIF- $1 \alpha$ expression by active berberine analogues was subsequently assessed by western blot assay in both T47D and MCF-7 cells under hypoxic condition. The cytotoxic effects of active berberine analogues were also evaluated on MCF-7 breast cancer cells.

\section{Results and discussion}

\section{Chemistry}

A series of 12-aryl berberine derivatives were prepared via Suzuki cross coupling reaction of 12-bromoberberine (2) with various arylboronic acids or heteroarylboronic acids (Scheme 1). 12-Bromoberberine (2) was firstly synthesized by bromination of berberine chloride with elemental bromine in dioxane

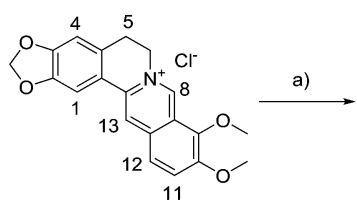

Berberine (1)

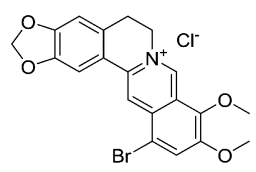

2

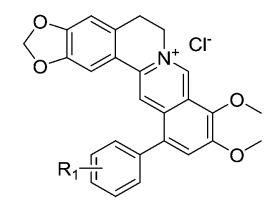

$3 \mathrm{R}_{1}=$ Alkyl, aryl etc

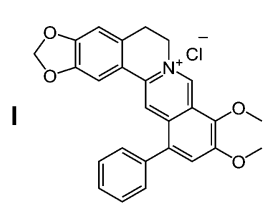

3a $(70 \%)$

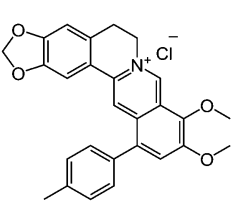

3b $(72 \%)$

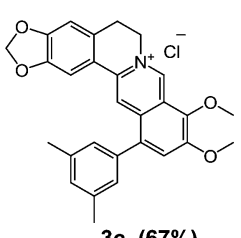

3c $(67 \%)$

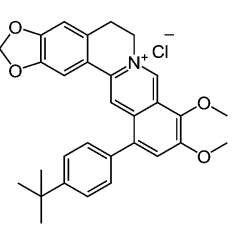

3d $(65 \%)$

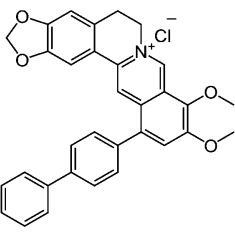

3e $(60 \%)$

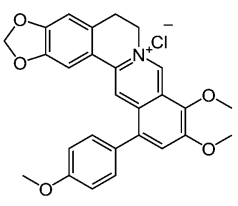

3f $(75 \%)$

II<smiles>COc1cc(-c2ccc(O)cc2)c2cc3[n+](cc2c1OC)CCc1cc2c(cc1-3)OCO2</smiles>

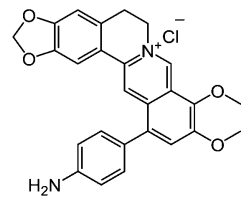

3h $(55 \%)$<smiles></smiles>

31 (60\%)

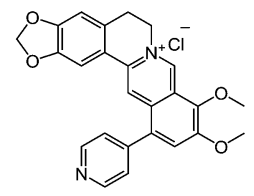

3o $(40 \%)$

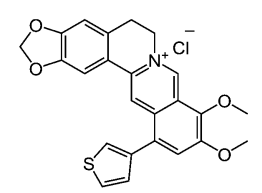

$3 p(43 \%)$

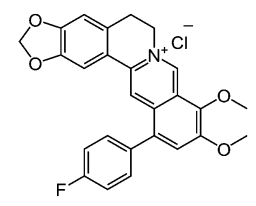

$3 k \quad(58 \%)$

IV

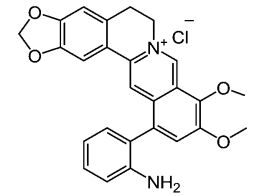

$3 i$ (52\%)<smiles>COc1cc(-c2ccccc2F)c2cc3[n+](cc2c1OC)CCc1cc2c(cc1-3)OCO2</smiles>

$3 \mathrm{~m}(52 \%)$

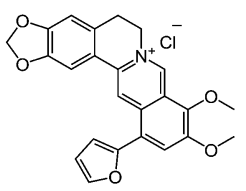

$3 q(50 \%)$<smiles>COc1cc(-c2ccc([N+](=O)[O-])cc2)c2cc3[n+](cc2c1OC)-c1cc2c(cc1CC3)OCO2</smiles>

3j (61\%)<smiles>COc1cc(-c2cccc(C(F)(F)F)c2)c2cc3[n+](cc2c1OC)CCc1cc2c(cc1-3)OCO2</smiles>

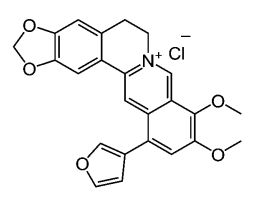

3r (45\%)

Scheme 1 Synthesis of 12 -aryl berberine analogues. Reagents and conditions: (a) $\mathrm{Br}_{2} /$ dioxane; (b) $\mathrm{RB}(\mathrm{OH})_{2} / \mathrm{Pd}(\mathrm{OAc})_{2} / \mathrm{Na}_{2} \mathrm{CO} 3 / \mathrm{EtOH}$. (I) Hydrophobic group bearing phenyl berberines; (II) hydrophilic group bearing phenyl berberines; (III) fluoro substituted phenyl berberines; (IV) heteroaromatic ring substituted berberines. All are isolated yields. 
according to the published method. ${ }^{38}$ Subsequently, 12-bromoberberine (2) was reacted with various arylboronic acids under the catalysis of palladium at room temperature to produce target 12-aryl berberine derivatives (3a-3r) by using Suzuki cross coupling reaction. A wide variety of arylboronic acids, from the electron-rich to electron-deficient nature, were successfully applied to the coupling reaction to afford four groups of 12-aryl berberine analogues, including hydrophobic group bearing phenyl berberines (3b-3f), hydrophilic group bearing phenyl berberines $(\mathbf{3} \mathbf{g}-\mathbf{3} \mathbf{j})$, fluoro substituted phenyl berberines (3k-3n) and heteroaromatic ring substituted berberines $(3 \mathbf{3 o}-\mathbf{3 r})$.

\section{Biological activity}

Compounds that inhibit HIF-1 transcriptional activity show great potential in anticancer therapy since HIF-1 plays an important role in many key aspects of cancer biology. A T47D (human ductal breast epithelial tumor) cell-based reporter assay was utilized to evaluate the inhibitory effects of 12-aryl berberine analogues (3a-3r), 2 and berberine on HIF-1 transcriptional activity. Briefly, T47D cells were transiently cotransfected with the hypoxia response element (HRE) luciferase and Renilla plasmids which contain reporter genes for hypoxia-inducible expression of firefly luciferase and constitutive expression of Renilla luciferase, respectively. ${ }^{10,11}$ The HRE contains essential binding sites for HIF-1, which mediates increased transcription in cells that are exposed to hypoxia. We could screen for compounds that specifically inhibit hypoxiainduced firefly luciferase activity driven by HIF-1 from the decreased ratio of firefly/Renilla luciferase activity under normoxia and hypoxia conditions. Digoxin, a well-studied HIF-1 inhibitor, ${ }^{10}$ was used as a positive control. The HIF-1 inhibitory effects of all berberine derivatives were firstly evaluated at a single concentration of $10 \mu \mathrm{M}$. As illustrated in Fig. 1, the

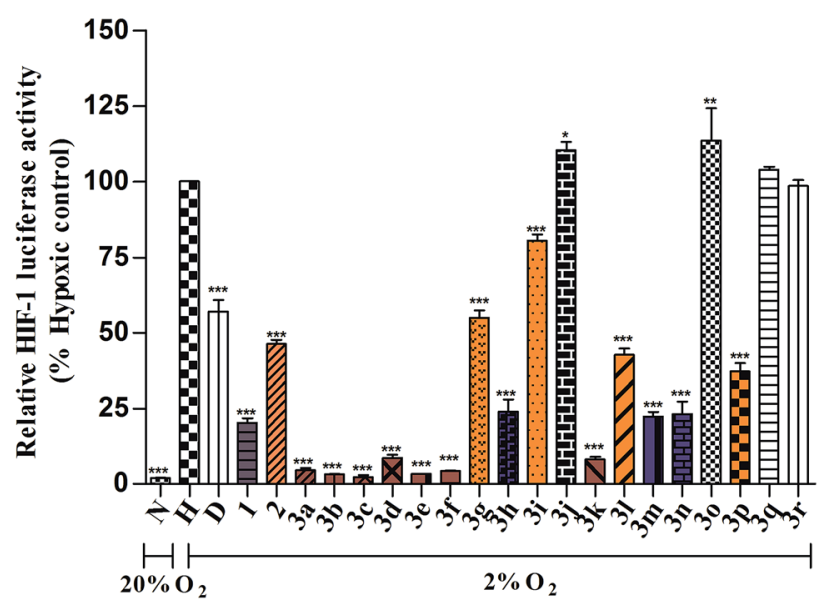

Fig. 1 Relative HIF-1 luciferase activity (\% hypoxic control) of berberine and its derivatives $(10 \mu \mathrm{M})$. N means normoxic condition $\left(20 \% \mathrm{O}_{2}\right), \mathrm{H}$ represents hypoxia condition $\left(2 \% \mathrm{O}_{2}\right)$, D stands for digoxin $(100 \mathrm{nM}) . * * * p<0.001, * * p<0.01$ or $* p<0.05$ for comparison between berberine analogue-treated group and the blank control group. relative HIF-1 luciferase activity of the transfected T47D cells cultured under normoxic conditions $\left(20 \% \mathrm{O}_{2}\right)$ and under hypoxic conditions $\left(2 \% \mathrm{O}_{2}\right)$ for $20 \mathrm{~h}$ were $1.8 \%$ and $100 \%$, respectively, displaying the ratio of firely/Renilla luciferase activity in hypoxic condition was 55.5-fold (100/1.8) higher than that in normoxic condition. Digoxin decreased HIF-1 luciferase activity from $100 \%$ in the blank control group to $57.0 \%$ under hypoxic condition $\left(2 \% \mathrm{O}_{2}\right)$ at the drug concentration of $100 \mathrm{nM}$, showing its suppressive effect on hypoxia-induced HIF-1 transcriptional activity. In the same way, berberine also significantly $(p<0.001)$ reduced the hypoxia-induced HIF-1 transcriptional activity to $20.2 \%$ (Fig. 1 ) at the tested concentration of $10 \mu \mathrm{M}$. Similarly, fifteen berberine derivatives $(\mathbf{2}, \mathbf{3 a}-\mathbf{3} \mathbf{i}, \mathbf{3 k} \mathbf{k}-\mathbf{3 n}, \mathbf{3} \mathbf{p})$ also showed inhibitory effects on hypoxia-induced HIF-1 transcriptional activity in various potency (Fig. 1). Compounds $\mathbf{3 a - 3 f}$ and 3k showed stronger HIF-1 inhibitory effects than their parent compound, berberine. The analogues $\mathbf{3 h}, \mathbf{3 m}$ and $3 \mathbf{n}$ displayed a comparable HIF-1 suppressing activity to berberine, while $\mathbf{3 g}$, $3 \mathbf{j}, 3 \mathbf{3}, 3 \mathbf{p}$ and 2 possessed weaker HIF-1 inhibiting activity than the parent berberine. However, compounds $\mathbf{3 j}$, 3o, $\mathbf{3 q}$ and $\mathbf{3 r}$ didn't demonstrate HIF-1 inhibitory activity at the tested concentration.

Based on the above screening result, berberine and nine active 12-aryl berberine derivatives (3a-3f, 3k-3m) were selected for further evaluation of their dose-dependent response for suppressing hypoxia-induced HIF-1 transcriptional activity. As a result (Table 1), all tested berberine derivatives exhibited inhibitory effect on hypoxia-induced HIF-1 transcriptional activity with $\mathrm{IC}_{50}$ values ranged from 0.74 to $11.82 \mu \mathrm{M}$, and berberine showed an $\mathrm{IC}_{50}$ value of $4.78 \mu \mathrm{M}$. The analogues 3a3f, 3k showed a 2.2-6.4 fold more potent inhibitory effects on HIF-1 transcriptional activity than the parent berberine, $\mathbf{3 m}$ exhibited comparable potency to berberine, while $\mathbf{3 l}$ still displayed weaker HIF-1 suppressing activity than berberine. The cell viability, as measured by the control Renilla luciferase activity, was more than $85 \%$ in the groups treated by berberine derivatives at the concentration around their $\mathrm{IC}_{50}$ values (Table S1†), indicating that all tested compounds effectively inhibited

Table 1 HIF-1 inhibitory activity in T47D cell and anti-proliferative effect on MCF-7 cell of active berberine analogues ${ }^{a}$

\begin{tabular}{lll}
\hline Compounds & $\begin{array}{l}\text { HIF-1 inhibitory activity } \\
\left(\mathrm{IC}_{50}, \mu \mathrm{M}\right)\end{array}$ & $\begin{array}{l}\text { Cytotoxicity on MCF-7 cell } \\
\left(\mathrm{IC}_{50}, \mu \mathrm{M}\right)\end{array}$ \\
\hline $\mathbf{1}$ & $4.78 \pm 0.73$ & $26.57 \pm 1.75$ \\
3a & $1.51 \pm 0.09^{* * *}$ & $5.58 \pm 2.10^{* * *}$ \\
3b & $1.39 \pm 0.07^{* * *}$ & $4.51 \pm 0.84^{* * *}$ \\
3c & $1.26 \pm 0.29^{* * *}$ & $2.74 \pm 0.06^{* * *}$ \\
3d & $2.12 \pm 0.36^{* * *}$ & $3.59 \pm 0.69^{* * *}$ \\
3e & $0.74 \pm 0.06^{* * *}$ & $0.98 \pm 0.07^{* * *}$ \\
3f & $1.35 \pm 0.14^{* * *}$ & $9.17 \pm 2.59^{* * *}$ \\
3k & $2.07 \pm 0.17^{* * *}$ & $8.45 \pm 0.22^{* * *}$ \\
31 & $11.82 \pm 1.65^{* * *}$ & $20.97 \pm 5.28$ \\
3m & $5.40 \pm 1.36$ & $17.05 \pm 4.03^{* * *}$
\end{tabular}

$a * * * p<0.001$ for comparison between groups treated by compounds and group treated by 1 . 
HIF-1 transcription without significant cytotoxicity at the concentrations at which they were active. ${ }^{\mathbf{4 6}}$

The structure-activity relationship (SAR) of these synthesized 12-aryl berberine analogues was analyzed and summarized as follows on the basis of the above results. Firstly, a phenyl substituent at C-12 of berberine contributes to the inhibitory effect on HIF-1 transcriptional activity, compared to heteroaromatic rings including pyridyl, thienyl and furyl substituents at C-12 of berberine. As illustrated in Fig. 2A, 3a containing a 12-phenyl substituent remarkably suppressed HIF1 transcriptional activity with an $\mathrm{IC}_{50}$ value of $1.51 \mu \mathrm{M}$. In sharp contrast, 3o, 3q and 3r with 12-heteroaromatic ring substituents did not show any suppressing effect on HIF-1 function at the tested concentration of $10 \mu \mathrm{M}$ and the inhibitory effect of $\mathbf{3 p}$ containing thienyl ring was much weaker than that of 3a. Thus, the phenyl substituent is a preferential pharmacophore over the substituents of pyridyl, thienyl and furyl for the HIF-1 inhibiting activity of 12-aryl berberine analogues. Secondly, 12-phenyls containing hydrophobic groups are beneficial to enhance HIF-1 suppressing effect, compared to those with hydrophilic ones

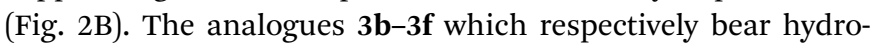
phobic $p$-methyl, 3,5-dimethyl, $p$-methoxyl, $p$-phenyl and $p$-tertbutyl moieties on their 12-phenyl substituent, exhibited inhibitory effect on HIF-1 transcriptional activity with $\mathrm{IC}_{50}$ values ranged from 0.74 to $2.12 \mu \mathrm{M}$. On the contrary, $3 \mathbf{g}, 3 \mathbf{i}$ and $3 \mathbf{j}$ with hydrophilic $p$-hydroxyl, $o$-amino groups, and $p$-nitryl on their 12-phenyl substituent did not display inhibition of HIF-1 function at the tested concentration of $10 \mu \mathrm{M}$. Notably, 12-

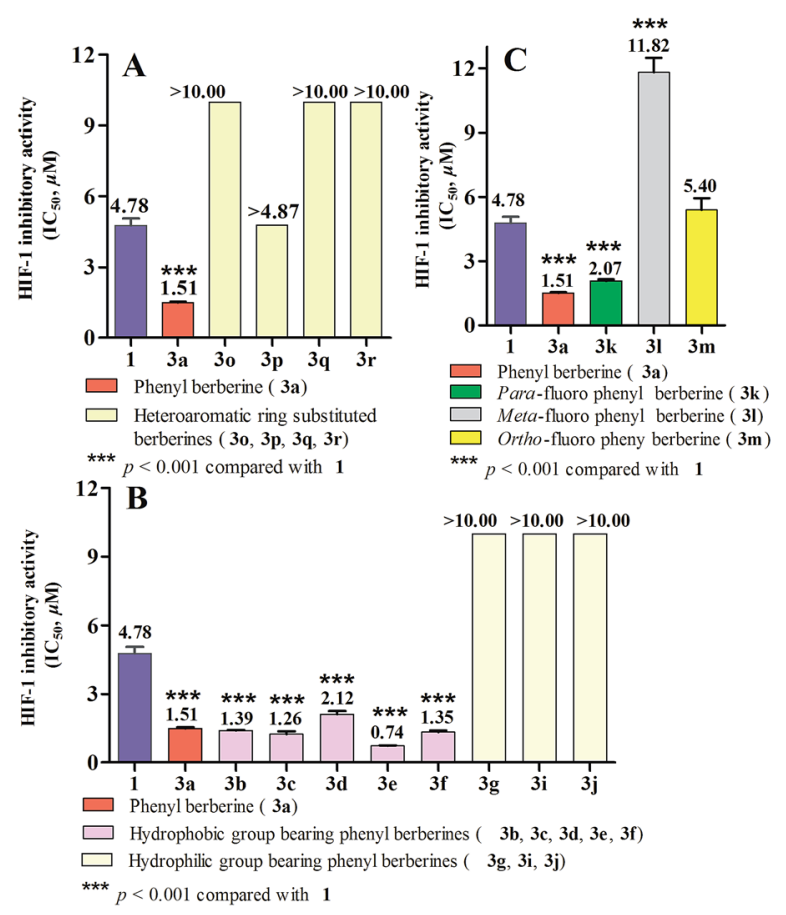

Fig. 2 HIF-1 inhibitory activity $\left(\mathrm{IC}_{50}\right)$ of 12 -aryl berberine derivatives. (A) Comparison of effect of phenyl and heteroaromatic rings substituents on HIF-1 function; (B) comparison of effect of hydrophobic and hydrophilic groups of phenyl berberines on HIF-1 function; (C) comparison of effect of fluoro substituted position of phenyl berberines on HIF-1 function. biphenyl substituted berberine (3e) demonstrated the most potent HIF-1 inhibitory effect among all 12-phenyl berberine analogues with an $\mathrm{IC}_{50}$ value of $0.74 \mu \mathrm{M}$. The introduction of the biphenyl substituent to berberine leads to an increase of a 5.5 fold potency over that of the parent berberine. Finally, the $p$ fluoro phenyl berberine (3k) showed stronger inhibitory effect on HIF-1 transcriptional activity than those with $m$ - and $o$-fluoro phenyl berberines $\mathbf{3 l}$ and $\mathbf{3 m}$, respectively (Fig. 2C). The $\mathrm{IC}_{50}$ value of 3k was $2.07 \mu \mathrm{M}$, which is a 5.7 and 2.6 fold more potent than that of $\mathbf{3 1}$ and $\mathbf{3 m}$, respectively. Collectively, the phenyls with hydrophobic and $p$-fluoro groups are favorable pharmacophores for enhancing HIF-1 inhibitory activity of 12-aryl berberine derivatives. Additionally, we also performed a calculation of $\log P(\operatorname{cog} P)$ using ChemDraw Ultra 12.0 to determine lipophilicity of berberine and selected derivatives (3a-3c, $\mathbf{3 e}$ and 3f) ${ }^{47,48}$ A modest inverse linear correlation of $\log \mathrm{IC}_{50}$ values and $\operatorname{cog} P$ was evident $\left(r^{2}=0.9133\right)$, suggesting that hydrophobicity of these 12-aryl berberine derivatives plays a significant role in their HIF-1 inhibitory activity (Fig. S1†).

The inhibitory effects of berberine and its analogues 3a-3f, $3 \mathbf{k}$ on the expression of HIF-1 $\alpha$ protein were also evaluated in
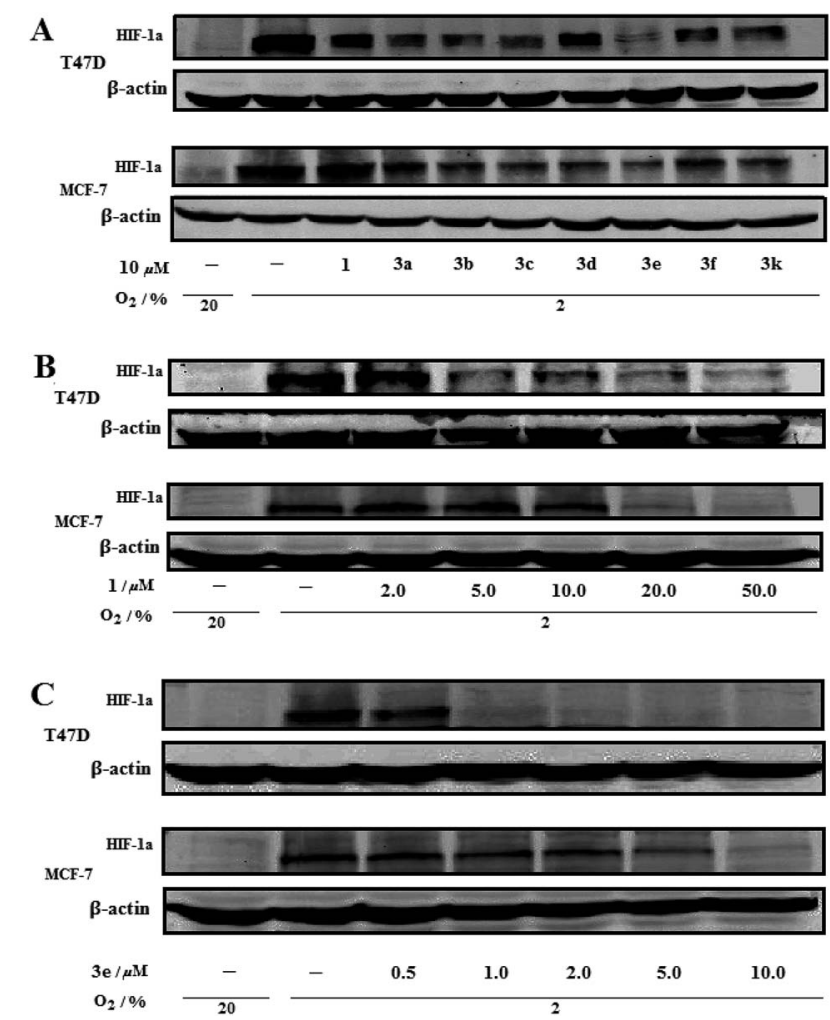

Fig. 3 Inhibition of hypoxia-induced expression of HIF-1 $\alpha$ protein in T47D and MCF-7 cells by berberine (1) and 12-aryl berberine derivatives. (A) T47D and MCF-7 cells were exposed to vehicle, $10 \mu \mathrm{M}$ of berberine (1), $3 \mathrm{a}-3 \mathrm{f}$ and $3 \mathrm{k}$ for $24 \mathrm{~h}$ under hypoxic $\left(2 \% \mathrm{O}_{2}\right)$ or normoxic conditions $\left(20 \% \mathrm{O}_{2}\right)$ and cell lysates were subjected to immunoblot assays for HIF- $1 \alpha$ and $\beta$-actin; (B) T47D and MCF-7 cells were exposed to vehicle or the indicated concentration of berberine (1) for $24 \mathrm{~h}$ under hypoxic $\left(2 \% \mathrm{O}_{2}\right)$ or normoxic conditions $\left(20 \% \mathrm{O}_{2}\right)$; (C) T47D and MCF-7 cells were exposed to vehicle or the indicated concentration of berberine analogue $3 e$ for $24 \mathrm{~h}$ under hypoxic $\left(2 \% \mathrm{O}_{2}\right)$ or normoxic conditions $\left(20 \% \mathrm{O}_{2}\right)$. 
both T47D and MCF-7 cells under hypoxic condition by using western blot analysis. As the results, 3a-3f and 3k showed more potent suppressive activities on hypoxia-induced expression of HIF- $1 \alpha$ protein than the parent berberine at a single concentration of $10 \mu \mathrm{M}$ (Fig. 3A). Dose-dependent responses were also observed for berberine and 3e that exposure of T47D and MCF-7 cells to berberine (2.0-50.0 $\mu \mathrm{M}$, Fig. 3B) and 3e (0.5-10.0 $\mu \mathrm{M}$, Fig. 3C) for $24 \mathrm{~h}$ inhibited hypoxia-induced expression of HIF-1 $\alpha$ protein. Obviously, 3 e exhibited much stronger inhibitory effect on the expression of HIF- $1 \alpha$ protein than berberine. All these results coincided with those of inhibitory effects on hypoxiainduced HIF-1 transcriptional activity.

The cytotoxic effects of compounds $\mathbf{3 a} \mathbf{a} \mathbf{3 f}, \mathbf{3 k} \mathbf{k} \mathbf{- 3} \mathbf{m}$ and berberine were evaluated on human breast cancer cell (MCF-7). As the result (Table 1), berberine exhibited cytotoxicity against MCF-7 cell with an $\mathrm{IC}_{50}$ value of $26.57 \mu \mathrm{M}$. Compound $3 \mathrm{e}$, the most potent HIF-1 inhibitor, showed the strongest cytotoxic effect among all tested compounds with an $\mathrm{IC}_{50}$ value of 0.98 $\mu \mathrm{M}$, which was a 27.1 fold potency of that of berberine. Compounds 3a-3d, 3f and 3k with stronger HIF-1 inhibitory activity significantly $(p<0.001)$ inhibited MCF-7 cell growth with $\mathrm{IC}_{50}$ values ranged from 2.74 to $9.17 \mu \mathrm{M}$, which were a 2.89.6 fold more toxic than that of berberine. However, $\mathbf{3 l}$ and $\mathbf{3 m}$ with weaker HIF-1 suppressing activity exhibited higher IC $_{50}$ value (20.97 and $17.05 \mu \mathrm{M}$, respectively) than the other tested berberine analogues.

\section{Conclusions}

Eighteen novel derivatives of 12-aryl substituted berberine were successfully synthesized by Suzuki cross coupling reaction and evaluated for their inhibitory effect on HIF-1 transcriptional activity. Seven berberine analogues (3a-3f, 3k) showed more potent $(p<0.001)$ HIF-1 suppressing effects than the parent berberine (1). Analysis of SAR suggested that phenyls containing hydrophobic moieties are preferential pharmacophores for the HIF-1 inhibitory activity of 12-aryl berberine analogues. Among all the berberine analogues, the 12-biphenyl berberine (3e) exhibited the most potent HIF-1 suppressing activity with a 5.4 fold enhancement of potency over the parent berberine. Berberine analogues 3a-3f and $\mathbf{3 k}$ demonstrated more potent inhibitory effects on hypoxia-induced expression of HIF-1 $\alpha$ protein in both T47D and MCF-7 cells than the parent berberine. In general, berberine analogues (3a-3f, 3k) with more potent HIF-1 inhibitory activity also exhibited more toxic effect on MCF-7 cancer cells. This study provided a series of promising berberine-based HIF-1 inhibitors. Additionally, it was the first report on berberine and its derivatives' inhibitory activity on HIF-1 transcriptional activity.

\section{Methods}

\section{General}

The ${ }^{1} \mathrm{H},{ }^{13} \mathrm{C}$ NMR experiments were measured on a Bruker Ascend ${ }^{\circledR} 600 \mathrm{NMR}$ spectrometer $\left(600 \mathrm{MHz}\right.$ for ${ }^{1} \mathrm{H}$ and $150 \mathrm{MHz}$ for ${ }^{13} \mathrm{C}$ ) with the solvent signal as internal reference. High resolution mass spectra (HRMS) were performed on an Agilent
6230 electrospray ionization (ESI) time-of-flight (TOF) mass spectrometer. UHPLC-DAD analyses were carried out on an Agilent 1290 Infinity LC system using an ACQUITY UPLC® BEH $\mathrm{C}_{18}$ column $\left(1.7 \mathrm{~mm}, 100 \times 2.1 \mathrm{~mm}\right.$, Waters $\left.{ }^{\circledR}\right)$, and all synthetic compounds were more than $95 \%$ in purity. Melting points are uncorrected and were measured on a MPA100 Optimelt Point Apparatus. Column chromatography was performed with Davisil silica gel (particle size 40-63 micron). Analytical thin layer chromatography (TLC) was performed on Merck silica gel $60-\mathrm{F}_{254}$ plates. Berberine hydrochloride and aromatic boronic acids were purchased from Acros. All other chemicals were purchased from 9dingchem. Unless otherwise specified, all fine chemicals were used as received.

\section{Synthesis of 12-bromoberberine chloride (2)}

Berberine chloride $(0.37 \mathrm{~g}, 1.0 \mathrm{mmol})$ was suspended in dioxane $(20 \mathrm{~mL})$. A solution of $\mathrm{Br}_{2}(0.5 \mathrm{~mL}, 9.7 \mathrm{mmol})$ in dioxane $(10 \mathrm{~mL})$ was added into the above berberine solution dropwise at room temperature. The reaction mixture was then stirred at room temperature for 4 days. The precipitate was filtered off and successively washed with $10 \% \mathrm{Na}_{2} \mathrm{~S}_{2} \mathrm{O}_{3}$ solution $(20 \mathrm{~mL} \times 2)$, $10 \% \mathrm{NaHCO}_{3}$ solution $(20 \mathrm{~mL} \times 2)$, and $20 \% \mathrm{KBr}$ solution $(20$ $\mathrm{mL} \times 2$ ). Then, the precipitate was completely dissolved in $\mathrm{AgCl}$ hot methanol solution. After filtration of the above solution, the methanol solution was evaporated and the residue was purified by silica gel chromatography to afford $2(0.31 \mathrm{~g}, 69 \%$ yield $)$. Its HRMS, ${ }^{1} \mathrm{H}-,{ }^{13} \mathrm{C}-\mathrm{NMR}$ and melt point data are in good agreement with those of 12-bromoberberine chloride in the literature. ${ }^{38}$

\section{General procedure for Suzuki cross coupling reaction}

A mixture of 12-bromoberberine (2, $10.0 \mathrm{mg}, 0.022 \mathrm{mmol})$, boronic acid (1.5 equiv.), palladium acetate $(0.45 \mathrm{mg}, 0.002$ $\mathrm{mmol})$ and sodium carbonate $(4.7 \mathrm{mg}, 0.044 \mathrm{mmol})$ was stirred in anhydrous ethanol $(2 \mathrm{~mL})$ at room temperature overnight. The reaction mixture was quenched with water and extracted with dichloromethane. The dichloromethane extract was washed with brine, and then dried over $\mathrm{MgSO}_{4}$. Then, the solvent was evaporated and the residue was purified by chromatography on silica gel to give yellowish solid of berberine derivatives. Finally, the yellowish solid was converted into chloride derivatives (3a-3r) of berberine either by $\mathrm{AgCl}$ in hot methanol or using column chromatography of ion-exchange Amberlite ${ }^{\circledR}$ IRA-400 (chloride form).

9,10-Dimethoxy-12-phenyl-5,6-dihydro-[1,3]dioxolo[4,5-g] isoquinolino[3,2-a]isoquinolin-7-ium chloride (3a). Purification by silica gel column chromatography (95:5 $\mathrm{CHCl}_{3} / \mathrm{MeOH}$ ) afforded $6.9 \mathrm{mg}(70 \%)$ of $3 \mathrm{a}$ as yellow solid. TLC $R_{\mathrm{f}}=0.28$ (95: 5 $\mathrm{CHCl}_{3} / \mathrm{MeOH}$ ); mp 206-208 ${ }^{\circ} \mathrm{C} ;{ }^{1} \mathrm{H}$ NMR (600 $\mathrm{MHz}, \mathrm{CDCl}_{3}$ ): $\delta 10.61(\mathrm{~s}, 1 \mathrm{H}), 8.11(\mathrm{~s}, 1 \mathrm{H}), 7.73(\mathrm{~s}, 1 \mathrm{H}), 7.58-7.61(\mathrm{~m}, 3 \mathrm{H}), 7.46-$ $7.48(\mathrm{~m}, 2 \mathrm{H}), 7.01(\mathrm{~s}, 1 \mathrm{H}), 6.81(\mathrm{~s}, 1 \mathrm{H}), 6.05(\mathrm{~s}, 2 \mathrm{H}), 5.33(\mathrm{t}, J=$ $6.0 \mathrm{~Hz}, 2 \mathrm{H}), 4.42(\mathrm{~s}, 3 \mathrm{H}), 4.08(\mathrm{~s}, 3 \mathrm{H}), 3.32(\mathrm{t}, J=6.0 \mathrm{~Hz}, 2 \mathrm{H}) ;{ }^{13} \mathrm{C}$ NMR $\left(150 \mathrm{MHz}, \mathrm{CDCl}_{3}\right): \delta$ 150.6, 150.3, 148.2, 147.7, 145.4, $137.8,136.9,135.9,131.5,130.8,129.72$, 129.3, 129.0, 126.5, 122.6, 120.4, 117.7, 108.8, 105.0, 102.1, 63.4, 57.1, 56.0, 27.8. 
HRMS (ESI): $m / z$ for $\mathrm{C}_{26} \mathrm{H}_{22} \mathrm{NO}_{4}[\mathrm{M}-\mathrm{Cl}]^{+}$calcd 412.1543 , found 412.1569.

9,10-Dimethoxy-12-( $p$-tolyl)-5,6-dihydro-[1,3]dioxolo[4,5-g] isoquinolino[3,2-a]isoquinolin-7-ium chloride (3b). Purification by silica gel column chromatography ( $95: 5 \mathrm{CHCl}_{3} / \mathrm{MeOH}$ ) afforded $7.3 \mathrm{mg}(72 \%)$ of $3 \mathbf{b}$ as yellow solid. TLC $R_{\mathrm{f}}=0.28$ (95: 5 $\left.\mathrm{CHCl}_{3} / \mathrm{MeOH}\right) ; \mathrm{mp} 205-207{ }^{\circ} \mathrm{C} ;{ }^{1} \mathrm{H}$ NMR $\left(600 \mathrm{MHz}, \mathrm{CDCl}_{3}\right)$ : $\delta 10.57(\mathrm{~s}, 1 \mathrm{H}), 8.13(\mathrm{~s}, 1 \mathrm{H}), 7.71(\mathrm{~s}, 1 \mathrm{H}), 7.40(\mathrm{~d}, J=7.8 \mathrm{~Hz}, 2 \mathrm{H})$, $7.35(\mathrm{~d}, J=7.8 \mathrm{~Hz}, 2 \mathrm{H}), 7.27(\mathrm{~s}, 1 \mathrm{H}), 7.03(\mathrm{~s}, 1 \mathrm{H}), 6.06(\mathrm{~s}, 2 \mathrm{H})$, $5.33(\mathrm{t}, J=6.0 \mathrm{~Hz}, 2 \mathrm{H}), 4.39(\mathrm{~s}, 3 \mathrm{H}), 4.08(\mathrm{~s}, 3 \mathrm{H}), 3.32(\mathrm{t}, J=$ $6.0 \mathrm{~Hz}, 2 \mathrm{H}), 2.52(\mathrm{~s}, 3 \mathrm{H}) ;{ }^{13} \mathrm{C}$ NMR $\left(150 \mathrm{MHz}, \mathrm{CDCl}_{3}\right): \delta 150.5$, $150.3,148.2$, 147.5, 145.2, 139.0, 137.7, 136.0, 133.9, 131.5, 130.8, 130.0, 129.6, 126.4, 122.6, 120.4, 117.9, 108.8, 105.0, 102.1, 63.3, 57.1, 56.0, 27.6, 21.3. HRMS (ESI): $\mathrm{m} / \mathrm{z}$ for $\mathrm{C}_{27} \mathrm{H}_{24} \mathrm{NO}_{4}[\mathrm{M}-\mathrm{Cl}]^{+}$calcd 426.1700 , found 426.1726 .

12-(3,5-Dimethylphenyl)-9,10-dimethoxy-5,6-dihydro-[1,3] dioxolo[4,5-g] isoquinolino[3,2-a]isoquinolin-7-ium chloride (3c). Purification by silica gel column chromatography ( $95: 5$ $\left.\mathrm{CHCl}_{3} / \mathrm{MeOH}\right)$ afforded $7.0 \mathrm{mg}(67 \%)$ of $3 \mathrm{c}$ as yellow solid. TLC $R_{\mathrm{f}}=0.28\left(95: 5 \mathrm{CHCl}_{3} / \mathrm{MeOH}\right) ; \mathrm{mp} 203-204{ }^{\circ} \mathrm{C} ;{ }^{1} \mathrm{H}$ NMR $(600$ $\left.\mathrm{MHz}, \mathrm{CDCl}_{3}\right): \delta 10.58(\mathrm{~s}, 1 \mathrm{H}), 8.11(\mathrm{~s}, 1 \mathrm{H}), 7.70(\mathrm{~s}, 1 \mathrm{H}), 7.20(\mathrm{~s}$, $1 \mathrm{H}), 7.05(\mathrm{~s}, 2 \mathrm{H}), 7.02(\mathrm{~s}, 1 \mathrm{H}), 6.82(\mathrm{~s}, 1 \mathrm{H}), 6.05(\mathrm{~s}, 2 \mathrm{H}), 5.33(\mathrm{t}, J$ $=6.0 \mathrm{~Hz}, 2 \mathrm{H}), 4.41(\mathrm{~s}, 3 \mathrm{H}), 4.08(\mathrm{~s}, 3 \mathrm{H}), 3.32(\mathrm{t}, J=6.0 \mathrm{~Hz}, 2 \mathrm{H})$, $2.45(\mathrm{~s}, 6 \mathrm{H}) ;{ }^{13} \mathrm{C}$ NMR $(150 \mathrm{MHz}, \mathrm{CDCl} 3): \delta 150.5,150.3,148.2$, $147.5,145.2$, 139.0, 137.6, 136.8, 136.3, 131.5, 130.8, 130.6, 127.5, 126.3, 122.5, 120.5, 117.9, 108.8, 105.0, 102.1, 63.3, 57.1, 56.0, 27.6, 21.4. HRMS (ESI): $m / z$ for $\mathrm{C}_{28} \mathrm{H}_{26} \mathrm{NO}_{4}[\mathrm{M}-\mathrm{Cl}]^{+}$calcd 440.1856 , found 440.1875 .

12-(4-(tert-Butyl)phenyl)-9,10-dimethoxy-5,6-dihydro-[1,3] dioxolo[4,5- $g$ ] isoquinolino[3,2-a]isoquinolin-7-ium chloride (3d). Purification by silica gel column chromatography $(95: 5$ $\left.\mathrm{CHCl}_{3} / \mathrm{MeOH}\right)$ afforded $5.3 \mathrm{mg}(63 \%)$ of $\mathbf{3 d}$ as yellow solid. TLC $R_{\mathrm{f}}=0.29\left(95: 5 \mathrm{CHCl}_{3} / \mathrm{MeOH}\right) ; \mathrm{mp} 207-209{ }^{\circ} \mathrm{C} ;{ }^{1} \mathrm{H}$ NMR $(600$ $\left.\mathrm{MHz}, \mathrm{CDCl}_{3}\right): \delta 10.59(\mathrm{~s}, 1 \mathrm{H}), 8.19(\mathrm{~s}, 1 \mathrm{H}), 7.72(\mathrm{~s}, 1 \mathrm{H}), 7.61(\mathrm{~d}, J$ $=8.4 \mathrm{~Hz}, 2 \mathrm{H}), 7.41(\mathrm{~d}, J=8.4 \mathrm{~Hz}, 2 \mathrm{H}), 7.07(\mathrm{~s}, 1 \mathrm{H}), 6.82(\mathrm{~s}, 1 \mathrm{H})$, $6.06(\mathrm{~s}, 2 \mathrm{H}), 5.32(\mathrm{t}, J=6.0 \mathrm{~Hz}, 2 \mathrm{H}), 4.40(\mathrm{~s}, 3 \mathrm{H}), 4.07(\mathrm{~s}, 3 \mathrm{H}), 3.31$ (t, $J=6.0 \mathrm{~Hz}, 2 \mathrm{H}), 1.44(\mathrm{~s}, 9 \mathrm{H}) ;{ }^{13} \mathrm{C}$ NMR $\left(150 \mathrm{MHz}, \mathrm{CDCl}_{3}\right)$ : $\delta 152.2$, 150.5, 150.3, 148.2, 147.6, 145.2, 137.7, 135.9, 134.0, 131.4, 130.9, 129.4, 126.6, 126.3, 122.6, 120.5, 117.9, 108.8, 105.1, 102.1, 63.3, 57.1, 56.0, 34.9, 31.4, 27.6. HRMS (ESI): $\mathrm{m} / \mathrm{z}$ for $\mathrm{C}_{30} \mathrm{H}_{30} \mathrm{NO}_{4}[\mathrm{M}-\mathrm{Cl}]^{+}$calcd 468.2169 , found 468.2180.

12-([1,1'-Biphenyl]-4-yl)-9,10-dimethoxy-5,6-dihydro-[1,3] dioxolo[4,5-g] isoquinolino[3,2-a]isoquinolin-7-ium chloride (3e). Purification by silica gel column chromatography ( $95: 5$ $\left.\mathrm{CHCl}_{3} / \mathrm{MeOH}\right)$ afforded $6.9 \mathrm{mg}(60 \%)$ of $3 e$ as yellow solid. TLC $R_{\mathrm{f}}=0.27\left(95: 5 \mathrm{CHCl}_{3} / \mathrm{MeOH}\right) ; \mathrm{mp} 208-210{ }^{\circ} \mathrm{C} ;{ }^{1} \mathrm{H}$ NMR $(600$ $\left.\mathrm{MHz}, \mathrm{CDCl}_{3}\right): \delta 10.64(\mathrm{~s}, 1 \mathrm{H}), 8.19(\mathrm{~s}, 1 \mathrm{H}), 7.83(\mathrm{~d}, J=7.8 \mathrm{~Hz}$, $2 \mathrm{H}), 7.78(\mathrm{~s}, 1 \mathrm{H}), 7.72(\mathrm{~d}, J=7.8 \mathrm{~Hz}, 2 \mathrm{H}), 7.52-7.56(\mathrm{~m}, 4 \mathrm{H}), 7.43$ $(\mathrm{t}, J=7.8 \mathrm{~Hz}, 1 \mathrm{H}), 7.06(\mathrm{~s}, 1 \mathrm{H}), 6.82(\mathrm{~s}, 1 \mathrm{H}), 6.04(\mathrm{~s}, 2 \mathrm{H}), 5.34(\mathrm{t}, J$ $=6.0 \mathrm{~Hz}, 2 \mathrm{H}), 4.41(\mathrm{~s}, 3 \mathrm{H}), 4.10(\mathrm{~s}, 3 \mathrm{H}), 3.31(\mathrm{t}, J=6.0 \mathrm{~Hz}, 2 \mathrm{H})$; ${ }^{13} \mathrm{C}$ NMR $\left(150 \mathrm{MHz}, \mathrm{CDCl}_{3}\right): \delta 150.6,150.3,148.3,147.8,145.5$, $141.9,140.0,137.8,135.7,135.5,131.4,130.9,130.2$, 129.1, 128.0, 128.0, 127.2, 126.5, 122.7, 120.4, 117.7, 108.8, 105.0, 102.1, 63.3, 57.1, 55.9, 27.6. HRMS (ESI): $m / z$ for $\mathrm{C}_{32} \mathrm{H}_{26} \mathrm{NO}_{4}[\mathrm{M}$ $-\mathrm{Cl}]^{+}$calcd 488.1856, found 488.1868.

9,10-Dimethoxy-12-(4-methoxyphenyl)-5,6-dihydro-[1,3]dioxolo[4,5-g]isoquinolino[3,2-a]isoquinolin-7-ium chloride (3f).
Purification by silica gel column chromatography $\left(95: 5 \mathrm{CHCl}_{3} /\right.$ $\mathrm{MeOH})$ afforded $7.9 \mathrm{mg}(75 \%)$ of $\mathbf{3 f}$ as yellow solid. TLC $R_{\mathrm{f}}=$ 0.27 (95 : $\left.5 \mathrm{CHCl}_{3} / \mathrm{MeOH}\right) ; \mathrm{mp} 194-196{ }^{\circ} \mathrm{C} ;{ }^{1} \mathrm{H} \mathrm{NMR}(600 \mathrm{MHz}$, $\left.\mathrm{CDCl}_{3}\right): \delta 10.58(\mathrm{~s}, 1 \mathrm{H}), 8.12(\mathrm{~s}, 1 \mathrm{H}), 7.70(\mathrm{~s}, 1 \mathrm{H}), 7.38(\mathrm{~d}, J=$ $8.4 \mathrm{~Hz}, 2 \mathrm{H}), 7.12(\mathrm{~d}, J=8.4 \mathrm{~Hz}, 2 \mathrm{H}), 7.04(\mathrm{~s}, 1 \mathrm{H}), 6.82(\mathrm{~s}, 1 \mathrm{H})$, $6.06(\mathrm{~s}, 2 \mathrm{H}), 5.32(\mathrm{t}, J=6.0 \mathrm{~Hz}, 2 \mathrm{H}), 4.39(\mathrm{~s}, 3 \mathrm{H}), 4.08(\mathrm{~s}, 3 \mathrm{H}), 3.95$ (s, 3H), $3.31(\mathrm{t}, J=6.0 \mathrm{~Hz}, 2 \mathrm{H}) ;{ }^{13} \mathrm{C}$ NMR $\left(150 \mathrm{MHz}, \mathrm{CDCl}_{3}\right)$ : $\delta$ 160.1 150.6, 150.3, 148.2, 147.5, 145.1, 137.6, 135.8, 131.7, $130.9,130.8,129.0,126.4,122.6,120.4,117.9,114.7$, 108.8, 105.0, 102.1, 63.3, 57.9, 55.9, 55.5, 27.6. HRMS (ESI): $\mathrm{m} / \mathrm{z}$ for $\mathrm{C}_{27} \mathrm{H}_{24} \mathrm{NO}_{5}[\mathrm{M}-\mathrm{Cl}]^{+}$calcd 442.1649, found 442.1664.

12-(4-Hydroxyphenyl)-9,10-dimethoxy-5,6-dihydro-[1,3]dioxolo[4,5-g] isoquinolino[3,2-a] isoquinolin-7-ium chloride (3g). Purification by silica gel column chromatography (gradient elution from $95: 5$ to $90: 10 \mathrm{CHCl}_{3} / \mathrm{MeOH}$ ) afforded $5.3 \mathrm{mg}$ (52\%) of $3 \mathrm{~g}$ as yellow solid. TLC $R_{\mathrm{f}}=0.24\left(95: 5 \mathrm{CHCl}_{3} / \mathrm{MeOH}\right)$; mp 198-200 ${ }^{\circ} \mathrm{C} ;{ }^{1} \mathrm{H}$ NMR $\left(600 \mathrm{MHz}, \mathrm{CDCl}_{3}\right): \delta 10.19(\mathrm{~s}, 1 \mathrm{H}), 8.05$ $(\mathrm{s}, 1 \mathrm{H}), 7.59(\mathrm{~s}, 1 \mathrm{H}), 7.05(\mathrm{~d}, J=8.4 \mathrm{~Hz}, 2 \mathrm{H}), 6.91(\mathrm{~d}, J=8.4 \mathrm{~Hz}$, $2 \mathrm{H}), 6.88(\mathrm{~s}, 1 \mathrm{H}), 6.80(\mathrm{~s}, 1 \mathrm{H}), 6.04(\mathrm{~s}, 2 \mathrm{H}), 5.17(\mathrm{t}, J=6.0 \mathrm{~Hz}$, $2 \mathrm{H}), 4.38(\mathrm{~s}, 3 \mathrm{H}), 4.05(\mathrm{~s}, 3 \mathrm{H}), 3.34(\mathrm{t}, J=6.0 \mathrm{~Hz}, 2 \mathrm{H}) ;{ }^{13} \mathrm{C} \mathrm{NMR}$ $\left(150 \mathrm{MHz}, \mathrm{CDCl}_{3}\right): \delta 157.8,150.6,150.2,148.3,146.7,144.4$, $137.4,136.2,131.4,130.5,130.3,127.4,126.2,122.5,120.4$, 118.2, 116.4, 108.6, 104.9, 102.1, 63.0, 57.1, 56.2, 27.5. HRMS (ESI): $\mathrm{m} / z$ for $\mathrm{C}_{26} \mathrm{H}_{22} \mathrm{NO}_{5}[\mathrm{M}-\mathrm{Cl}]^{+}$calcd 428.1492 , found 428.1528 .

12-(4-Aminophenyl)-9,10-dimethoxy-5,6-dihydro-[1,3]dioxolo $[4,5-g]$ isoquinolino[3,2-a]isoquinolin-7-ium chloride (3h). Purification by silica gel column chromatography (gradient elution from $95: 5$ to $\left.90: 10 \mathrm{CHCl}_{3} / \mathrm{MeOH}\right)$ afforded $5.6 \mathrm{mg}(55 \%)$ of $3 \mathbf{h}$ as yellow solid. TLC $R_{\mathrm{f}}=0.21\left(95: 5 \mathrm{CHCl}_{3} / \mathrm{MeOH}\right) ; \mathrm{mp} \mathrm{178-}$ $180{ }^{\circ} \mathrm{C} ;{ }^{1} \mathrm{H}$ NMR $\left(600 \mathrm{MHz}, \mathrm{CDCl}_{3}\right): \delta 10.52(\mathrm{~s}, 1 \mathrm{H}), 8.19(\mathrm{~s}, 1 \mathrm{H})$, $7.68(\mathrm{~s}, 1 \mathrm{H}), 7.24(\mathrm{~d}, J=8.4 \mathrm{~Hz}, 2 \mathrm{H}), 7.06(\mathrm{~s}, 1 \mathrm{H}), 6.87(\mathrm{~d}, J=$ $8.4 \mathrm{~Hz}, 2 \mathrm{H}), 6.81(\mathrm{~s}, 1 \mathrm{H}), 6.06(\mathrm{~s}, 2 \mathrm{H}), 5.31(\mathrm{t}, J=6.0 \mathrm{~Hz}, 2 \mathrm{H}), 4.38$ (s, 3H), $4.07(\mathrm{~s}, 3 \mathrm{H}), 3.31(\mathrm{t}, J=6.0 \mathrm{~Hz}, 2 \mathrm{H}) ;{ }^{13} \mathrm{C} \mathrm{NMR}(150 \mathrm{MHz}$, $\left.\mathrm{CDCl}_{3}\right): \delta 150.49,150.42,148.23,147.26,147.21,144.67,137.44$, $136.43,131.69,130.76,130.67,126.47,126.07,122.64,120.50$, 118.13, 115.43, 108.73, 104.97, 102.08, 63.28, 57.03, 55.94, 27.60. HRMS (ESI): $m / z$ for $\mathrm{C}_{26} \mathrm{H}_{23} \mathrm{~N}_{2} \mathrm{O}_{4}[\mathrm{M}-\mathrm{Cl}]^{+}$calcd 427.1652, found 427.1658 .

12-(2-Aminophenyl)-9,10-dimethoxy-5,6-dihydro-[1,3]dioxolo [4,5-g]isoquinolino[3,2-a]isoquinolin-7-ium chloride (3i). Purification by silica gel column chromatography (gradient elution from $95: 5$ to $\left.90: 10 \mathrm{CHCl}_{3} / \mathrm{MeOH}\right)$ afforded $5.3 \mathrm{mg}(52 \%)$ of $3 \mathbf{i}$ as yellow solid. TLC $R_{\mathrm{f}}=0.22$ (95: $5 \mathrm{CHCl}_{3} / \mathrm{MeOH}$ ); mp 182$184^{\circ} \mathrm{C} ;{ }^{1} \mathrm{H}$ NMR $\left(600 \mathrm{MHz}, \mathrm{CDCl}_{3}\right): \delta 10.50(\mathrm{~s}, 1 \mathrm{H}), 7.91(\mathrm{~s}, 1 \mathrm{H})$, $7.78(\mathrm{~s}, 1 \mathrm{H}), 7.35-7.37(\mathrm{~m}, 1 \mathrm{H}), 7.12(\mathrm{dd}, J=7.8,1.2 \mathrm{~Hz}, 1 \mathrm{H})$, $7.06(\mathrm{~s}, 1 \mathrm{H}), 6.93-6.95(\mathrm{~m}, 1 \mathrm{H}), 6.90(\mathrm{dd}, J=7.8,0.6 \mathrm{~Hz}, 1 \mathrm{H})$, $6.80(\mathrm{~s}, 1 \mathrm{H}), 6.04(\mathrm{~s}, 2 \mathrm{H}), 5.32-5.37(\mathrm{~m}, 1 \mathrm{H}), 5.20-5.24(\mathrm{~m}, 1 \mathrm{H})$, $4.41(\mathrm{~s}, 3 \mathrm{H}), 4.07(\mathrm{~s}, 3 \mathrm{H}), 3.33-3.38(\mathrm{~m}, 1 \mathrm{H}), 3.24-3.29(\mathrm{~m}, 1 \mathrm{H})$; ${ }^{13} \mathrm{C}$ NMR $\left(150 \mathrm{MHz}, \mathrm{CDCl}_{3}\right): \delta 150.6,150.6,148.2,147.4,145.5$, $144.3,137.8,133.0,131.5,131.2,130.6,130.5,127.6,122.7$, 121.3, 120.5, 118.8, 118.5, 116.1, 108.6, 105.3, 102.1, 63.2, 57.1, 56.1, 27.5. HRMS (ESI): $m / z$ for $\mathrm{C}_{26} \mathrm{H}_{23} \mathrm{~N}_{2} \mathrm{O}_{4}[\mathrm{M}-\mathrm{Cl}]^{+}$calcd 427.1652, found 427.1663 .

9,10-Dimethoxy-12-(4-nitrophenyl)-5,6-dihydro-[1,3]dioxolo [4,5-g] isoquinolino[3,2-a]isoquinolin-7-ium chloride (3j). Purification by silica gel column chromatography $\left(95: 5 \mathrm{CHCl}_{3} /\right.$ 
$\mathrm{MeOH})$ afforded $5.6 \mathrm{mg}(61 \%)$ of $3 \mathbf{j}$ as yellow solid. TLC $R_{\mathrm{f}}=$ 0.28 (95 : $5 \mathrm{CHCl}_{3} / \mathrm{MeOH}$ ); mp $190-192{ }^{\circ} \mathrm{C} ;{ }^{1} \mathrm{H}$ NMR $(600 \mathrm{MHz}$, $\left.\mathrm{CDCl}_{3}\right): \delta 10.65(\mathrm{~s}, 1 \mathrm{H}), 8.48(\mathrm{~d}, J=8.4 \mathrm{~Hz}, 2 \mathrm{H}), 7.94(\mathrm{~s}, 1 \mathrm{H}), 7.73$ $(\mathrm{s}, 1 \mathrm{H}), 7.68(\mathrm{~d}, J=8.4 \mathrm{~Hz}, 2 \mathrm{H}), 6.99(\mathrm{~s}, 1 \mathrm{H}), 6.82(\mathrm{~s}, 1 \mathrm{H}), 6.06(\mathrm{~s}$, $2 \mathrm{H}), 5.31(\mathrm{t}, J=6.0 \mathrm{~Hz}, 2 \mathrm{H}), 4.46(\mathrm{~s}, 3 \mathrm{H}), 4.10(\mathrm{~s}, 3 \mathrm{H}), 3.34(\mathrm{t}, J=$ $6.0 \mathrm{~Hz}, 2 \mathrm{H}) ;{ }^{13} \mathrm{C} \mathrm{NMR}\left(150 \mathrm{MHz}, \mathrm{CDCl}_{3}\right): \delta 150.9,150.1,148.4$, 148.2, 148.2, 146.7, 143.4, 138.4, 132.8, 131.0, 130.8, 126.7, 124.6, 122.5, 120.0, 116.6, 108.8, 104.9, 102.2, 63.4, 57.3, 56.1, 27.5. HRMS (ESI): $m / z$ for $\mathrm{C}_{26} \mathrm{H}_{21} \mathrm{~N}_{2} \mathrm{O}_{6}[\mathrm{M}-\mathrm{Cl}]^{+}$calcd 457.1394, found 457.1412 .

12-(4-Fluorophenyl)-9,10-dimethoxy-5,6-dihydro-[1,3]dioxolo [4,5-g] isoquinolino[3,2-a]isoquinolin-7-ium chloride (3k). Purification by silica gel column chromatography (95:5 $\mathrm{CHCl}_{3} /$ $\mathrm{MeOH})$ afforded $5.9 \mathrm{mg}(58 \%)$ of $3 \mathbf{k}$ as yellow solid. TLC $R_{\mathrm{f}}=$ 0.28 (95 : $5 \mathrm{CHCl}_{3} / \mathrm{MeOH}$ ); mp $196-198{ }^{\circ} \mathrm{C} ;{ }^{1} \mathrm{H}$ NMR $(600 \mathrm{MHz}$, $\left.\mathrm{CDCl}_{3}\right): \delta 10.59(\mathrm{~s}, 1 \mathrm{H}), 8.02(\mathrm{~s}, 1 \mathrm{H}), 7.70(\mathrm{~s}, 1 \mathrm{H}), 7.45(\mathrm{~d}, J=$ $5.4 \mathrm{~Hz}, 2 \mathrm{H}), 7.44(\mathrm{~d}, J=5.4 \mathrm{~Hz}, 2 \mathrm{H}), 7.01(\mathrm{~s}, 1 \mathrm{H}), 6.82(\mathrm{~s}, 1 \mathrm{H})$, $6.06(\mathrm{~s}, 2 \mathrm{H}), 5.32(\mathrm{t}, J=6.0 \mathrm{~Hz}, 2 \mathrm{H}), 4.42(\mathrm{~s}, 3 \mathrm{H}), 4.08(\mathrm{~s}, 3 \mathrm{H}), 3.33$ $(\mathrm{t}, J=6.0 \mathrm{~Hz}, 2 \mathrm{H}) ;{ }^{13} \mathrm{C} \mathrm{NMR}\left(150 \mathrm{MHz}, \mathrm{CDCl}_{3}\right): \delta 162.3(\mathrm{~d}, J=$ $250.49 \mathrm{~Hz}), 150.7,150.2$, 148.3, 147.7, 145.6, 137.9, 134.7, 132.8 $(\mathrm{d}, J=3.02 \mathrm{~Hz}), 131.4(\mathrm{~d}, J=7.55 \mathrm{~Hz}), 130.9,126.6,122.5,120.3$, 117.4, 116.4 (d, $J=22.64 \mathrm{~Hz}), 108.8,104.9$, 102.2, 63.3, 57.2, 56.0, 27.5. HRMS (ESI): $m / z$ for $\mathrm{C}_{26} \mathrm{H}_{21} \mathrm{FNO}_{4}[\mathrm{M}-\mathrm{Cl}]^{+}$calcd 430.1449 , found 430.1477 .

12-(3-Fluorophenyl)-9,10-dimethoxy-5,6-dihydro-[1,3]dioxolo [4,5-g] isoquinolino[3,2-a]isoquinolin-7-ium chloride (31). Purification by silica gel column chromatography (95:5 $\mathrm{CHCl}_{3} /$ $\mathrm{MeOH})$ afforded $6.1 \mathrm{mg}(60 \%)$ of 31 as yellow solid. TLC $R_{\mathrm{f}}=$ 0.28 (95 : $\left.5 \mathrm{CHCl}_{3} / \mathrm{MeOH}\right)$; mp $197-199{ }^{\circ} \mathrm{C} ;{ }^{1} \mathrm{H}$ NMR $(600 \mathrm{MHz}$, $\left.\mathrm{CDCl}_{3}\right): \delta 10.62(\mathrm{~s}, 1 \mathrm{H}), 8.06(\mathrm{~s}, 1 \mathrm{H}), 7.72(\mathrm{~s}, 1 \mathrm{H}), 7.57-7.59(\mathrm{~m}$, 1H), 7.25-7.29 (m, 2H), 7.18-7.20 (m, 1H), $7.02(\mathrm{~s}, 1 \mathrm{H}), 6.82(\mathrm{~s}$, $1 \mathrm{H}), 6.06(\mathrm{~s}, 2 \mathrm{H}), 5.33(\mathrm{t}, J=6.0 \mathrm{~Hz}, 2 \mathrm{H}), 4.42(\mathrm{~s}, 3 \mathrm{H}), 4.08(\mathrm{~s}$, $3 \mathrm{H}), 3.33(\mathrm{t}, J=6.0 \mathrm{~Hz}, 2 \mathrm{H}) ;{ }^{13} \mathrm{C} \mathrm{NMR}\left(150 \mathrm{MHz}, \mathrm{CDCl}_{3}\right): \delta 162.2$ $(\mathrm{d}, J=248.68 \mathrm{~Hz}), 150.7,150.2,148.3,147.8,145.9,138.9(\mathrm{~d}, J=$ $20.98 \mathrm{~Hz}) 138.0,134.2(\mathrm{~d}, J=3.02 \mathrm{~Hz}), 131.3,131.0(\mathrm{~d}, J=7.55$ $\mathrm{Hz}), 130.9,126.6,125.5$ (d, $J=2.72 \mathrm{~Hz}), 122.5,120.2,117.3$, 116.8 (d, $J=22.03 \mathrm{~Hz}), 116.0$ (d, $J=20.98 \mathrm{~Hz}), 108.8,105.0$, 102.1, 63.4, 57.2, 56.0, 27.5. HRMS (ESI): $m / z$ for $\mathrm{C}_{26} \mathrm{H}_{21} \mathrm{FNO}_{4}[\mathrm{M}$ $-\mathrm{Cl}]^{+}$calcd 430.1449 , found 430.1462 .

12-(2-Fluorophenyl)-9,10-dimethoxy-5,6-dihydro-[1,3]dioxolo $[4,5-g]$ isoquinolino[3,2-a]isoquinolin-7-ium chloride (3m). Purification by silica gel column chromatography (95:5 $\mathrm{CHCl}_{3}$ / $\mathrm{MeOH})$ afforded $5.3 \mathrm{mg}(52 \%)$ of $3 \mathrm{~m}$ as yellow solid. TLC $R_{\mathrm{f}}=$ 0.28 (95 : $5 \mathrm{CHCl}_{3} / \mathrm{MeOH}$ ); mp $194-197{ }^{\circ} \mathrm{C} ;{ }^{1} \mathrm{H}$ NMR $(600 \mathrm{MHz}$, $\left.\mathrm{CDCl}_{3}\right): \delta 10.64(\mathrm{~s}, 1 \mathrm{H}), 7.87(\mathrm{~d}, J=2.4 \mathrm{~Hz}, 1 \mathrm{H}), 7.75(\mathrm{~s}, 1 \mathrm{H})$, 7.57-7.61 (m, 1H), 7.39-7.44 (m, 2H), 7.33-7.56 (m, 1H), 7.03 (s, $1 \mathrm{H}), 6.82(\mathrm{~s}, 1 \mathrm{H}), 6.06(\mathrm{~s}, 2 \mathrm{H}), 5.49-5.53(\mathrm{~m}, 1 \mathrm{H}), 5.16-5.19(\mathrm{~m}$, $1 \mathrm{H}), 4.43(\mathrm{~s}, 3 \mathrm{H}), 4.08(\mathrm{~s}, 3 \mathrm{H}), 3.40-3.42(\mathrm{~m}, 1 \mathrm{H}), 3.24-3.28(\mathrm{~m}$, $1 \mathrm{H}) ;{ }^{13} \mathrm{C}$ NMR $\left(150 \mathrm{MHz}, \mathrm{CDCl}_{3}\right): \delta 158.8(\mathrm{~d}, J=248.68 \mathrm{~Hz})$, $150.7,150.2,148.2,147.7,146.1,138.0,132.1(\mathrm{~d}, J=2.11 \mathrm{~Hz})$, $131.7,131.3$ (d, $J=7.70 \mathrm{~Hz}), 131.0,129.2,127.7,125.2(\mathrm{~d}, J=$ $3.32 \mathrm{~Hz}), 124.1$ (d, $J=15.39 \mathrm{~Hz}), 122.5,120.3,117.6$ (d, $J=2.26$ $\mathrm{Hz}$ ), 116.4 (d, $J=22.03 \mathrm{~Hz}$ ), 108.8, 105.0, 102.1, 63.3, 57.2, 56.0, 27.6. HRMS (ESI): $m / z$ for $\mathrm{C}_{26} \mathrm{H}_{21} \mathrm{FNO}_{4}[\mathrm{M}-\mathrm{Cl}]^{+}$calcd 430.1449, found 430.1436 .

9,10-Dimethoxy-12-(3-(trifluoromethyl)phenyl)-5,6-dihydro$[1,3]$ dioxolo[ $[4,5-g]$ isoquinolino[3,2-a]isoquinolin-7-ium chloride (3n). Purification by silica gel column chromatography (95: 5 $\left.\mathrm{CHCl}_{3} / \mathrm{MeOH}\right)$ afforded $7.3 \mathrm{mg}(64 \%)$ of $3 \mathbf{n}$ as yellow solid. TLC $R_{\mathrm{f}}=0.29$ (95: $\left.5 \mathrm{CHCl}_{3} / \mathrm{MeOH}\right) ; \operatorname{mp} 176-178{ }^{\circ} \mathrm{C} ;{ }^{1} \mathrm{H}$ NMR $(600$ $\left.\mathrm{MHz}, \mathrm{CDCl}_{3}\right): \delta 10.65(\mathrm{~s}, 1 \mathrm{H}), 7.98(\mathrm{~s}, 1 \mathrm{H}), 7.85(\mathrm{~d}, J=7.2 \mathrm{~Hz}, 1 \mathrm{H})$, 7.75-7.77 (m, 1H), 7.75 (s, 1H), $7.73(\mathrm{~s}, 1 \mathrm{H}), 7.68(\mathrm{~d}, J=7.2 \mathrm{~Hz}$, $1 \mathrm{H}), 6.98(\mathrm{~s}, 1 \mathrm{H}), 6.82(\mathrm{~s}, 1 \mathrm{H}), 6.06(\mathrm{~s}, 2 \mathrm{H}), 5.31(\mathrm{t}, J=6.0 \mathrm{~Hz}, 2 \mathrm{H})$, $4.44(\mathrm{~s}, 3 \mathrm{H}), 4.10(\mathrm{~s}, 3 \mathrm{H}), 3.33(\mathrm{t}, J=6.0 \mathrm{~Hz}, 2 \mathrm{H}) ;{ }^{13} \mathrm{C} \mathrm{NMR}(150$ $\left.\mathrm{MHz}, \mathrm{CDCl}_{3}\right): \delta 150.8,150.2,148.4,148.0,146.2,138.2,137.7$, 133.8, 133.1, 132.2 (q, $J=32.90 \mathrm{~Hz}$ ) 131.3, 130.9, 129.9, 126.7, $126.7(\mathrm{q}, J=4.53 \mathrm{~Hz}), 126.5(\mathrm{q}, J=272.83 \mathrm{~Hz}), 125.8(\mathrm{q}, J=3.32$ $\mathrm{Hz}), 122.5$, 120.2 , 117.0, 108.8, 104.9, 102.2, 63.4, 57.2, 56.0, 27.5. HRMS (ESI): $m / z$ for $\mathrm{C}_{27} \mathrm{H}_{21} \mathrm{~F}_{3} \mathrm{NO}_{4}[\mathrm{M}-\mathrm{Cl}]^{+}$calcd 480.1417, found 480.1430 .

9,10-Dimethoxy-12-(pyridin-4-yl)-5,6-dihydro-[1,3]dioxolo [4,5-g]isoquinolino[3,2-a]isoquinolin-7-ium chloride (3o). Purification by silica gel column chromatography (gradient elution from $95: 5$ to $\left.90: 10 \mathrm{CHCl}_{3} / \mathrm{MeOH}\right)$ afforded $4.0 \mathrm{mg}(40 \%)$ of 30 as yellow solid. TLC $R_{\mathrm{f}}=0.20$ (95: $5 \mathrm{CHCl}_{3} / \mathrm{MeOH}$ ); mp 200$202{ }^{\circ} \mathrm{C} ;{ }^{1} \mathrm{H}$ NMR $\left(600 \mathrm{MHz}, \mathrm{CDCl}_{3}\right): \delta 10.60(\mathrm{~s}, 1 \mathrm{H}), 8.88(\mathrm{~d}, J=$ $6.0 \mathrm{~Hz}, 2 \mathrm{H}), 8.02(\mathrm{~s}, 1 \mathrm{H}), 7.72(\mathrm{~s}, 1 \mathrm{H}), 7.43(\mathrm{~d}, J=6.0 \mathrm{~Hz}, 2 \mathrm{H})$, $7.01(\mathrm{~s}, 1 \mathrm{H}), 6.82(\mathrm{~s}, 1 \mathrm{H}), 6.07(\mathrm{~s}, 2 \mathrm{H}), 5.29(\mathrm{t}, J=6.0 \mathrm{~Hz}, 2 \mathrm{H}), 4.44$ $(\mathrm{s}, 3 \mathrm{H}), 4.10(\mathrm{~s}, 3 \mathrm{H}), 3.33(\mathrm{t}, J=6.0 \mathrm{~Hz}, 2 \mathrm{H}) ;{ }^{13} \mathrm{C} \mathrm{NMR}(150 \mathrm{MHz}$, $\left.\mathrm{CDCl}_{3}\right): \delta 150.9,150.8,150.2,148.4,148.2,146.6,144.8,138.4$, $132.4,131.0,130.8,126.5,124.5,122.5,120.1,116.6,108.8$, $104.9,102.2,63.4,57.3,56.1,27.5$. HRMS (ESI): $m / z$ for $\mathrm{C}_{25} \mathrm{H}_{21} \mathrm{~N}_{2} \mathrm{O}_{4}[\mathrm{M}-\mathrm{Cl}]^{+}$calcd 413.1496, found 413.1499.

9,10-Dimethoxy-12-(thiophen-3-yl)-5,6-dihydro-[1,3] dioxolo [4,5-g] isoquinolino[3,2-a]isoquinolin-7-ium chloride (3p). Purification by silica gel column chromatography (95:5 $\mathrm{CHCl}_{3} /$ $\mathrm{MeOH}$ ) afforded $4.3 \mathrm{mg}(43 \%)$ of $3 \mathrm{p}$ as yellow solid. TLC $R_{\mathrm{f}}=$ 0.27 (95 : $5 \mathrm{CHCl}_{3} / \mathrm{MeOH}$ ); $\mathrm{mp} 198-200{ }^{\circ} \mathrm{C} ;{ }^{1} \mathrm{H} \mathrm{NMR}(600 \mathrm{MHz}$, $\left.\mathrm{CDCl}_{3}\right): \delta 10.58(\mathrm{~s}, 1 \mathrm{H}), 8.23(\mathrm{~s}, 1 \mathrm{H}), 7.76(\mathrm{~s}, 1 \mathrm{H}), 7.62(\mathrm{dd}, J=4.8$, $3.0 \mathrm{~Hz}, 1 \mathrm{H}), 7.49$ (d, J=3.0 Hz, 1H), 7.29 (d, J=4.8 Hz, 1H), 7.09 $(\mathrm{s}, 1 \mathrm{H}), 6.82(\mathrm{~s}, 1 \mathrm{H}), 6.07(\mathrm{~s}, 2 \mathrm{H}), 5.32(\mathrm{t}, J=6.0 \mathrm{~Hz}, 2 \mathrm{H}), 4.30(\mathrm{~s}$, $3 \mathrm{H}), 4.08(\mathrm{~s}, 3 \mathrm{H}), 3.33(\mathrm{t}, J=6.0 \mathrm{~Hz}, 2 \mathrm{H}) ;{ }^{13} \mathrm{C}$ NMR $(150 \mathrm{MHz}$, $\left.\mathrm{CDCl}_{3}\right): \delta 150.6,150.3,148.3,147.6,145.5,137.9,131.7,130.9$, $130.9,130.7,128.6,127.6,126.3,125.1,122.6,120.4,117.6$, 108.8, 105.0, 102.1, 63.3, 57.1, 56.0, 27.6. HRMS (ESI): $m / z$ for $\mathrm{C}_{24} \mathrm{H}_{20} \mathrm{NO}_{4} \mathrm{~S}[\mathrm{M}-\mathrm{Cl}]^{+}$calcd 418.1108, found 418.1133.

12-(Furan-2-yl)-9,10-dimethoxy-5,6-dihydro-[1,3]dioxolo[4,5g]isoquinolino[3,2-a]isoquinolin-7-ium chloride (3q). Purification by silica gel column chromatography ( $95: 5 \mathrm{CHCl}_{3} / \mathrm{MeOH}$ ) afforded $4.8 \mathrm{mg}$ (50\%) of 3q as yellow solid. TLC $R_{\mathrm{f}}=0.27$ (95: 5 $\mathrm{CHCl}_{3} / \mathrm{MeOH}$ ); mp 191-193 ${ }^{\circ} \mathrm{C} ;{ }^{1} \mathrm{H}$ NMR (600 $\mathrm{MHz}, \mathrm{CDCl}_{3}$ ): $\delta 10.63(\mathrm{~s}, 1 \mathrm{H}), 8.72(\mathrm{~s}, 1 \mathrm{H}), 7.96(\mathrm{~s}, 1 \mathrm{H}), 7.73(\mathrm{~d}, J=1.8 \mathrm{~Hz}, 1 \mathrm{H})$, $7.28(\mathrm{~s}, 1 \mathrm{H}), 6.85(\mathrm{~s}, 1 \mathrm{H}), 6.82(\mathrm{~d}, J=3.6 \mathrm{~Hz}, 1 \mathrm{H}), 6.69(\mathrm{dd}, J=$ 3.6, $1.8 \mathrm{~Hz}, 1 \mathrm{H}), 6.10(\mathrm{~s}, 2 \mathrm{H}), 5.34(\mathrm{t}, J=6.0 \mathrm{~Hz}, 2 \mathrm{H}), 4.41(\mathrm{~s}, 3 \mathrm{H})$, $4.11(\mathrm{~s}, 3 \mathrm{H}), 3.33(\mathrm{t}, J=6.0 \mathrm{~Hz}, 2 \mathrm{H}) ;{ }^{13} \mathrm{C} \mathrm{NMR}\left(150 \mathrm{MHz}, \mathrm{CDCl}_{3}\right)$ : $\delta 150.7,150.3,150.2,148.4,147.7,146.0,144.0,138.0,130.9$, $129.9,124.4,124.0,122.7,120.4$, 117.6, 112.3, 110.6, 108.8, 105.0, 102.2, 63.4, 57.1, 55.9, 27.6. HRMS (ESI): $m / z$ for $\mathrm{C}_{24} \mathrm{H}_{20} \mathrm{NO}_{5}[\mathrm{M}-\mathrm{Cl}]^{+}$calcd 402.1336, found 402.1343.

12-(Furan-3-yl)-9,10-dimethoxy-5,6-dihydro-[1,3]dioxolo[4,5$g]$ isoquinolino[3,2-a]isoquinolin-7-ium chloride (3r). Purification by silica gel column chromatography (95:5 $\mathrm{CHCl}_{3} / \mathrm{MeOH}$ ) afforded $4.3 \mathrm{mg}(45 \%)$ of $3 \mathrm{r}$ as yellow solid. TLC $R_{\mathrm{f}}=0.26$ (95: 5 
$\mathrm{CHCl}_{3} / \mathrm{MeOH}$ ); mp 192-194 ${ }^{\circ} \mathrm{C} ;{ }^{1} \mathrm{H}$ NMR (600 $\mathrm{MHz}, \mathrm{CDCl}_{3}$ ): $\delta 10.57(\mathrm{~s}, 1 \mathrm{H}), 8.29(\mathrm{~s}, 1 \mathrm{H}), 7.73(\mathrm{~s}, 2 \mathrm{H}), 7.71(\mathrm{~s}, 1 \mathrm{H}), 7.15(\mathrm{~s}, 1 \mathrm{H})$, $6.83(\mathrm{~s}, 1 \mathrm{H}), 6.69(\mathrm{~s}, 1 \mathrm{H}), 6.09(\mathrm{~s}, 2 \mathrm{H}), 5.33(\mathrm{t}, J=6.0 \mathrm{~Hz}, 2 \mathrm{H}), 4.40$ $(\mathrm{s}, 3 \mathrm{H}), 4.09(\mathrm{~s}, 3 \mathrm{H}), 3.33(\mathrm{t}, J=6.0 \mathrm{~Hz}, 2 \mathrm{H}) ;{ }^{13} \mathrm{C} \mathrm{NMR}(150 \mathrm{MHz}$, $\left.\mathrm{CDCl}_{3}\right): \delta 150.7,150.4,148.4,147.6,145.5,144.4,140.9,137.9$, $131.8,130.9,126.7,126.3,122.7,121.9,120.3$, 117.4, 111.6, 108.8, 104.9, 102.2, 63.3, 57.1, 56.0, 27.6. HRMS (ESI): $m / z$ for $\mathrm{C}_{24} \mathrm{H}_{20} \mathrm{NO}_{5}[\mathrm{M}-\mathrm{Cl}]^{+}$calcd 402.1336, found 402.1372.

\section{Reporter assay for inhibiting HIF-1 transcriptional activity ${ }^{11}$}

Berberine and its analogues were dissolved in DMSO to $10 \mathrm{mM}$ as stock solution and then diluted in DMEM media to appropriate concentration. T47D cells (American Type Culture Collection) were cultured in DMEM medium (Invitrogen), supplemented with $10 \%(\mathrm{v} / \mathrm{v})$ fetal bovine serum (FBS) (Invitrogen), $100 \mathrm{U} \mathrm{mL}^{-1}$ penicillin, and $100 \mu \mathrm{g} \mathrm{mL}{ }^{-1}$ streptomycin (Invitrogen) in a humidified atmosphere (5\% $\mathrm{CO}_{2}$ and $95 \%$ air) at $37{ }^{\circ} \mathrm{C}$. Cells $\left(5 \times 10^{6}\right.$ cells $)$ were co-transfected with the HREluciferase (Addgene) and Renilla plasmids using Lipofectamine 2000 (Invitrogen) according to the manufacturer's protocol. The transfected cells were seeded in 96-well plates with a density of $3 \times 10^{4}$ per well and cultured in DMEM with $10 \%$ FBS overnight. After addition of berberine analogues with different concentrations $(0.3-50 \mu \mathrm{M})$, the cells were incubated for $1 \mathrm{~h}$, and then were exposed to the hypoxic $\left(2 \% \mathrm{O}_{2} / 5 \% \mathrm{CO}_{2} /\right.$ $93 \% \mathrm{~N}_{2}$ ) or normoxic $\left(5 \% \mathrm{CO}_{2} / 95 \%\right.$ air) conditions at $37{ }^{\circ} \mathrm{C}$ for $20 \mathrm{~h}$. Then the cells were finally lysed, and luciferase activities of both HRE and Renilla were measured by Dual-Luciferase ${ }^{\circledR}$ reporter assay (Promega) kit according to manufacturer's instructions by using a multimode reader (Infinite $200 \mathrm{PRO}$, Tecan). HIF-1 transcriptional activity was shown by the ratio of firefly/Renilla luciferase activity. $\mathrm{IC}_{50}$ values were determined from the dose-response curves using the Prsim software. The data were repeated by three independent experiments.

\section{Western blot assay}

T47D or MCF-7 cells, at a density of $1 \times 10^{6}$ cells per well, were seeded in 6-well plates and cultured for 24 hours to allow attachment. Various concentrations of berberine and its derivatives were added to the cells which were incubated under hypoxic condition $\left(2 \% \mathrm{O}_{2}, 5 \% \mathrm{CO}_{2}\right.$, and $\left.93 \% \mathrm{~N}_{2}\right)$ for 24 hours. Meanwhile, vehicle treatment was also performed as control under both hypoxic and normoxic conditions in parallel. The supernatant was removed and each well of cells was lysed with RIPA buffer (Cell Signaling Technology) containing protease inhibitor cocktail (Roche). Cell lysates were then harvested into $0.5 \mathrm{~mL}$ microtube and boiled at $99{ }^{\circ} \mathrm{C}$ for 10 minutes. Subsequently, the total proteins of lysates were separated by $8 \%$ SDS polyacrylamide gel electrophoresis. After separation, the proteins in the gel were transferred onto nitrocellulose membranes (Pall), and the transferred membranes were blocked with $5 \%$ nonfat dry milk in $1 \times$ TBST for 1 hour at room temperature. After being washed three times in $1 \times$ TBST, these parts of membranes containing target HIF- $1 \alpha$ and reference $\beta$ actin proteins were divided apart according to the protein markers, and incubated respectively in corresponding primary mouse anti-human HIF- $1 \alpha$ antibody (BD Biosciences) at a dilution of $1: 200(\mathrm{v} / \mathrm{v})$ and mouse anti-human $\beta$-actin antibody (Santa Cruz Biotechnology) at a dilution of $1: 8000(\mathrm{v} / \mathrm{v})$. After overnight incubation at $4{ }^{\circ} \mathrm{C}$, the primary antibodies were washed away with $1 \times$ TBST, and IRDye-conjugated goat antimouse secondary antibodies (LI-COR Biosciences) were added at a ratio of $1: 5000(\mathrm{v} / \mathrm{v})$ for HIF-1 $\alpha$ and $1: 20000(\mathrm{v} / \mathrm{v})$ for $\beta$ actin for 1 hour incubation at room temperature. After three washes with $1 \times$ TBST, the membranes were scanned with an Odyssey infrared fluorescent scanner (LI-COR Biosciences). Finally, the amounts of proteins were characterized according to the optical densities of the bands. The amount of $\beta$-actin was served as a loading control.

\section{Cytotoxic assay on MCF-7 breast cancer cell}

MCF-7 cell line (American Type Culture Collection) was cultured in DMEM medium (Invitrogen) supplemented with $10 \%(\mathrm{v} / \mathrm{v})$ heat-inactivated fetal bovine serum (FBS), penicillin (100 U $\left.\mathrm{mL}^{-1}\right)$ and streptomycin $\left(10 \mu \mathrm{g} \mathrm{mL}^{-1}\right)$ in a humidified atmosphere of $5 \% \mathrm{CO}_{2} / 95 \%$ air at $37^{\circ} \mathrm{C}$. Cells were seeded in 96 -well microplates at a density of $5 \times 10^{3}$ cells per well $(100 \mu \mathrm{L})$, and cultured at $37{ }^{\circ} \mathrm{C}$ under $5 \% \mathrm{CO}_{2} / 95 \%$ air for $24 \mathrm{~h}$. Then, the cells were treated with fresh medium containing berberine analogues with appropriate concentrations $(0.3-50 \mu \mathrm{M})$ and further cultured for $72 \mathrm{~h}$. After that, the supernatant in each well was removed and the cell was gently washed by phosphate buffered saline (PBS) to avoid the possible effect of tested compounds on the following MTT assay. A volume of $100 \mu \mathrm{L}$ medium containing $0.5 \mathrm{mg} \mathrm{mL}{ }^{-1}$ MTT was added into each well and further cultured for $4 \mathrm{~h}$ at $37^{\circ} \mathrm{C}$. Then, the supernatant was discarded and the formed formazan crystals were dissolved in DMSO $(100 \mu \mathrm{L})$. Cell viability was determined by measuring the absorbance of each well at $570 \mathrm{~nm}$ using a microplate reader (Infinite $200 \mathrm{PRO}$, Tecan). The $\mathrm{IC}_{50}$ values (concentration that inhibits $50 \%$ of cell growth) of tested compounds were calculated using the GraphPad Prism 6 software. All assays were conducted in triplicate in three independent experiments. Data was expressed as mean $\pm \mathrm{SD}(n=3)$.

\section{Acknowledgements}

This research was financially supported by the Macao Science and Technology Development Fund, MSAR (056/2013/A2 to Dr Li-Ping Bai). The content is solely the responsibility of the authors. The funders had no role in study design, data collection and analysis, decision to publish, or preparation of the manuscript.

\section{Notes and references}

1 A. L. Harris, Nat. Rev. Cancer, 2002, 2, 38-47.

2 M. C. Brahimi-Horn, J. Chiche and J. Pouyssegur, J. Mol. Med., 2007, 85, 1301-1307.

3 P. Carmeliet, Y. Dor, J.-M. Herbert, D. Fukumura, K. Brusselmans, M. Dewerchin, M. Neeman, F. Bono, R. Abramovitch, P. Maxwell, C. J. Koch, P. Ratcliffe, 
L. Moons, R. K. Jain, D. Collen and E. Keshet, Nature, 1998, 394, 485-490.

4 G. L. Wang and G. L. Semenza, J. Biol. Chem., 1995, 270, 1230-1237.

5 A. Giaccia, B. G. Siim and R. S. Johnson, Nat. Rev. Drug Discovery, 2003, 2, 803-811.

6 R. Sheng, S. Li, G. Lin, S. Shangguan, Y. Gu, N. Qiu, J. Cao, Q. He, B. Yang and Y. Hu, RSC Adv., 2015, 5, 81817-81830.

7 D. G. Nagle and Y. D. Zhou, Curr. Drug Targets, 2006, 7, 355369.

8 H. S. Ban, Y. Uto and H. Nakamura, Expert Opin. Ther. Pat., 2011, 21, 131-146.

9 H. S. Ban, Y. Uto, M. Won and H. Nakamura, Expert Opin. Ther. Pat., 2016, 26, 309-322.

10 H. Zhang, D. Z. Qian, Y. S. Tan, K. Lee, P. Gao, Y. R. Ren, S. Rey, H. Hammers, D. Chang, R. Pili, C. V. Dang, J. O. Liu and G. L. Semenza, Proc. Natl. Acad. Sci. U. S. A., 2008, 105, 19579-19586.

11 S. Parhira, G.-Y. Zhu, R.-W. Jiang, L. Liu, L.-P. Bai and Z.-H. Jiang, Sci. Rep., 2014, 4, srep04748.

12 N. J. Mabjeesh, D. E. Post, M. T. Willard, B. Kaur, E. G. Van Meir, J. W. Simons and H. Zhong, Cancer Res., 2002, 62, 2478-2482.

13 A. L. Kung, S. D. Zabludoff, D. S. France, S. J. Freedman, E. A. Tanner, A. Vieira, S. Cornell-Kennon, J. Lee, B. Wang, J. Wang, K. Memmert, H.-U. Naegeli, F. Petersen, M. J. Eck, K. W. Bair, A. W. Wood and D. M. Livingston, Cancer Cell, 2004, 6, 33-43.

14 T. W. Hodges, C. F. Hossain, Y. P. Kim, Y. D. Zhou and D. G. Nagle, J. Nat. Prod., 2004, 67, 767-771.

15 C.-Y. Chen, G.-Y. Zhu, J.-R. Wang and Z.-H. Jiang, RSC Adv., 2016, 6, 79958-79967.

16 S. Lin, S. C. Tsai, C. C. Lee, B. W. Wang, J. Y. Liou and K. G. Shyu, Mol. Pharmacol., 2004, 66, 612-619.

17 L. Fu, W. Chen, W. Guo, J. Wang, Y. Tian, D. Shi, X. Zhang, H. Qiu, X. Xiao, T. Kang, W. Huang, S. Wang and W. Deng, PLoS One, 2013, 8, e69240.

18 C. Zhang, X. Yang, Q. Zhang, B. Yang, L. Xu, Q. Qin, H. Zhu, J. Liu, J. Cai, G. Tao, J. Ma, X. Ge, S. Zhang, H. Cheng and X. Sun, Acta Oto-Laryngol., 2014, 134, 185-192.

19 Q. Zhang, C. Zhang, X. Yang, B. Yang, J. Wang, Y. Kang, Z. Wang, D. Li, G. Huang, Z. Ma, X. Sun, J. Cai, G. Tao, S. Dai, W. Mao and J. Ma, Diagn. Pathol., 2014, 9, 98.

20 A. Kumar, E. Ekavali, K. Chopra, M. Mukherjee, R. Pottabathini and D. K. Dhull, Eur. J. Pharmacol., 2015, 761, 288-297.

21 M. Tillhon, L. M. Guaman Ortiz, P. Lombardi and A. I. Scovassi, Biochem. Pharmacol., 2012, 84, 1260-1267.

22 A. Pirillo and A. L. Catapano, Atherosclerosis, 2015, 243, 449461.

23 Y. Hu, E. A. Ehli, J. Kittelsrud, P. J. Ronan, K. Munger, T. Downey, K. Bohlen, L. Callahan, V. Munson, M. Jahnke, L. L. Marshall, K. Nelson, P. Huizenga, R. Hansen, T. J. Soundy and G. E. Davies, Phytomedicine, 2012, 19, 861-867.

24 N. Wang, H. Y. Tan, L. Li, M. F. Yuen and Y. Feng, J. Ethnopharmacol., 2015, 176, 35-48.
25 C.-L. Kuo, C.-W. Chi and T.-Y. Liu, Cancer Lett., 2004, 203, 127-137.

26 E. N. Simões Pires, R. L. Frozza, J. B. Hoppe, B. d. M. Menezes and C. G. Salbego, Brain Res., 2014, 1557, 26-33.

27 K. Karaosmanoglu, N. A. Sayar, I. A. Kurnaz and B. S. Akbulut, OMICS, 2014, 18, 42-53.

28 Z. J. Huang, Y. Zeng, P. Lan, P. H. Sun and W. M. Chen, MiniRev. Med. Chem., 2011, 11, 1122-1129.

29 S. Q. Wen, P. Jeyakkumar, S. R. Avula, L. Zhang and C. H. Zhou, Bioorg. Med. Chem. Lett., 2016, 26, 2768-2773.

30 P. Jeyakkumar, L. Zhang, S. R. Avula and C. H. Zhou, Eur. J. Med. Chem., 2016, 122, 205-215.

31 S. Zhang, X. Wang, W. Yin, Z. Liu, M. Zhou, D. Xiao, Y. Liu and D. Peng, Bioorg. Med. Chem. Lett., 2016, 26, 4799-4803.

32 X. Jin, L. Yan, H.-j. Li, R.-L. Wang, Z.-L. Hu, Y.-Y. Jiang, Y.-B. Cao, T.-H. Yan and Q.-Y. Sun, Adv. Anticancer Agents Med. Chem., 2015, 15, 89-98.

33 T. Su, S. Xie, H. Wei, J. Yan, L. Huang and X. Li, Bioorg. Med. Chem., 2013, 21, 5830-5840.

34 L. Zhang, J.-J. Chang, S.-L. Zhang, G. L. V. Damu, R.-X. Geng and C.-H. Zhou, Bioorg. Med. Chem., 2013, 21, 4158-4169.

35 D. Bhowmik, F. Buzzetti, G. Fiorillo, F. Orzi, T. M. Syeda, P. Lombardi and G. S. Kumar, MedChemComm, 2014, 5, 226-231.

36 Z. Cheng, A. F. Chen, F. Wu, L. Sheng, H. K. Zhang, M. Gu, Y. Y. Li, L. N. Zhang, L. H. Hu, J. Y. Li and J. Li, Bioorg. Med. Chem., 2010, 18, 5915-5924.

37 M. Tera, T. Hirokawa, S. Okabe, K. Sugahara, H. Seimiya and K. Shimamoto, Chem.-Eur. J., 2015, 21, 14519-14528.

38 K. Iwasa, D.-U. Lee, S.-I. Kang and W. Wiegrebe, J. Nat. Prod., 1998, 61, 1150-1153.

39 I. V. Nechepurenko, U. A. Boyarskikh, N. I. Komarova, M. P. Polovinka, M. L. Filipenko, G. I. Lifshits, N. F. Salakhutdinov and G. A. Tolstikov, Dokl. Chem., 2011, 439, 204-208.

40 W.-H. Chen, Y. Qin, Z. Cai, C.-L. Chan, G.-A. Luo and Z.-H. Jiang, Bioorg. Med. Chem., 2005, 13, 1859-1866.

41 J.-Y. Pang, Y. Qin, W.-H. Chen, G.-A. Luo and Z.-H. Jiang, Bioorg. Med. Chem., 2005, 13, 5835-5840.

42 W. H. Chen, J. Y. Pang, Y. Qin, Q. Peng, Z. Cai and Z. H. Jiang, Bioorg. Med. Chem. Lett., 2005, 15, 2689-2692.

43 Y. Qin, J. Y. Pang, W. H. Chen, Z. Cai and Z. H. Jiang, Bioorg. Med. Chem., 2006, 14, 25-32.

44 Y.-H. Long, L.-P. Bai, Y. Qin, J.-Y. Pang, W.-H. Chen, Z. Cai, Z.-L. Xu and Z.-H. Jiang, Bioorg. Med. Chem., 2006, 14, 4670-4676.

45 Y. Qin, J.-Y. Pang, W.-H. Chen, Z.-Z. Zhao, L. Liu and Z.-H. Jiang, Chem. Biodiversity, 2007, 4, 481-487.

46 S. Parhira, G.-Y. Zhu, M. Chen, L.-P. Bai and Z.-H. Jiang, J. Ethnopharmacol., 2016, 194, 930-936.

47 M. Ishikawa and Y. Hashimoto, J. Med. Chem., 2011, 54, 1539-1554.

48 A. L. Wolfe, K. K. Duncan, J. P. Lajiness, K. Zhu, A. S. Duerfeldt and D. L. Boger, J. Med. Chem., 2013, 56, 6845-6857. 